\title{
A STUDY ON THE ABILITY OF THE SECOND YEAR STUDENTS OF SMP N 18 PEKANBARU IN COMPREHENDING PROCEDURE TEXTS
}

\author{
Ervina Nova Purba ${ }^{1}$ and Effendi Gultom ${ }^{2^{*}}$ \\ 'Teachers' Training and Education Faculty, Riau University Graduate \\ ${ }^{2}$ English Lecturer, Teachers' Training and Education, Riau University \\ E-mail : effendygultom@gmail.com
}

\begin{abstract}
The objective of this study is to find out the ability of the second year students of SMP N 18 Pekanbaru in comprehending procedure texts. Based on the result of the data analysis in chapter IV, the writer makes some conclusions. Among 40 students, no student is in excellent level and very poor level, 13 students (32.5\%) are in good level, 25 students (62.5\%) are in mediocre level, 2 students (5\%) are in poor level. The mean score of the whole students in comprehending procedure texts is 57.81 . In conclusion, the ability of the second year students of SMP N 18 Pekanbaru in comprehending procedure texts is at mediocre level. Since the research dealt with comprehending procedure texts, the writer drew conclusions for each classification of comprehending procedure texts. In terms of finding main idea, from 40 students, 5 students (12.5\%) are in excellent level, 24 students (60\%) are in good level, 3 students $(7.5 \%)$ are in mediocre level, 7 students (17.5\%) are in poor level and 1 student (2.5\%) is in very poor level. In terms of finding factual information, 4 students (10\%) are in excellent level, 24 students (60.\%) are in good level, 8 students (20\%) are in mediocre level, 3 students $(7.5 \%)$ are in poor level and 1 student $(2,5 \%)$ is in very poor level. In terms of finding meaning of difficult word, 6 students (15\%) are in excellent level, 21 students $(52,5 \%)$ are in good level, 10 students (25\%) are in mediocre level, 2 students (5\%) are in poor level and 1 students $(2.5 \%)$ is in verypoor level. In terms of identifying reference, no student (o\%) is in excellent level, 11 students (27.5\%) are in good level, 13 students (32.5\%) are in mediocre level, 14 students (35\%) are in poor level and 2 students (5\%) are in very poor level. In terms of making restatement, from 2 students (5\%) are inexcellentlevel, 10 students (25\%) are in good level, 12 students (30\%) are in mediocre level, 16 students (40\%) are in poor level and no student (o\%) is in very poor level.

Keywords : Comprehending Procedure Texts, Study On Ability
\end{abstract}

\section{INTRODUCTION}

Reading is one of the skills that students should have in learning English. The purpose of reading is decoding information from text into one's mind (Nuttal, 1982:3). A person may read to gain information, existing knowledge or to criticize a writing style. A person may also read for enjoyment, or enhance knowledge of the language being read. Taking those as the consideration, the purposes of reading guide the reader's selection of texts. 
Based on the writer's experience when doing teaching practice at SMP N 18 Pekanbaru, many students there were not interested in reading. The school library had very few visitors. Students preferred going to the canteen than going to the library. They liked to spend their time just having fun with friends. Many students faced difficulties in comprehending reading texts. Some of their problems were: to find main ideas and supporting details. They translated it into Indonesian language first before getting the idea of the texts. They did not have enough vocabulary. As a result, they became bored and sleepy while reading the texts. Consequently, their grades were low.

Good readers are expected to understand what they are reading. Therefore, texts should contain words and grammatical structures which are familiar to the learners. Based on the school Curriculum, the basic goals of reading instructions for learners of SMP students are: (1) improving their language development; (2) giving them personal knowledge of the function of reading; (3) helping them to learn about books and the importance of reading.

At SMP level, the students are introduced procedure texts starting from the second semester. Procedure text is one kind of factual genre. There are three kinds of procedure text; (1) procedure text about instruction; (2) procedure text about how to make something or activity; (3) procedure text about how to behave. The social function of procedure text tells us how something is accomplished through a sequence of actions or steps. It shows a process in order. A procedure text consists of goal, materials, and steps. Aim or goal is the purpose of making something. Material is the ingredients that we need in making something. The methods or step is the way how to make something. By reading a procedure text, students will be able to enlarge their knowledge and improve their reading skills. Beverly Derewianka (1992: 3) states that a procedure text or instruction is a very important genre in our society because it enables us to get things done, and it is equally common in the oral and written modes. It means that a procedure text is commonly found and has influenced the daily life activities such as recipes and manuals which are examples of procedure texts.

After interviewing some English teachers of SMP N 18 Pekanbaru, the writer got information that the students got problems in comprehending procedure texts. The problems might be due to the lack of vocabulary mastery, lack of ability in dealing with structure, and the difficulty of the materials. In this research, the writer chose the procedure text as an instrument to find out the ability of the second year students of SMP N 18 Pekanbaru in comprehending procedure texts. The objective of the research is to find out the ability of the second year students of SMP N 18 Pekanbaru in comprehending procedure texts.

\section{METHODOLOGY}


This is a descriptive research that it has only one variable namely, to describe the students' ability in comprehending procedure texts. Rezeki (2002:13) states that the description is about the fact and characteristic of population. Gay (1990:10) says that a descriptive research involves collecting data to test hypothesis or to answer questions concerning the status of the study. The location of this research is SMP N 18 Pekanbaru which is located at Jl. Lily Pekanbaru. It was conducted from September to October 2010, in academic year 2009-2010.

There are 270 second year students at SMP N 18 Pekanbaru. They are divided into seven classes.Because the population is quite large and has the same characteristics, the writer takes a sample. A sample is a group in a research study in which information is obtained. According to Gay (2000:129) if the population is more than one hundred, the minimum sample taken is $15 \%$ from the population. If the population is less than 100, the sample that can be taken is 50 $\%$. So, the writer will took $15 \%$ of the population. The number of the sample is $270 \times 15 \%=40$. So, there are 40 students as samples.

The sample was taken by using cluster-sampling technique. According to Sudjana (1998:173) in cluster sampling the population is divided into some groups/clusters. These clusters will be taken in random process. Every member in a cluster that has been taken randomly will be a sample. The writer named cards based on every second year class at SMP N 18 Pekanbaru. They are class VIIIA, VIIIB, VIIIC, VIIID, VIIIE, VIIIF, and VIIIG. After mixing these cards for a moment, the writer took one card randomly as a sample of research and the chosen class became the sample. Then, by using lottery system, the writer chooses 40 students from the chosen class as the sample of this research.

The writer used a test as the instrument to collect the data. The tests consist of 40 items. The students were asked to answer the test correctly based on the provided procedure texts. The test items were adapted from several books for junior high school students.

Table 1: The Blue Print of the Test Items

\begin{tabular}{|c|c|}
\hline Main idea & $1,6,11,16,21,26,31,36$ \\
\hline Finding factual information & $2,7,12,17,22,27,32,37$ \\
\hline Meaning of difficult word & $3,8,13,18,23,28,33,38$ \\
\hline Reference & $4,9,14,19,24,29,34,39$ \\
\hline Restatement / Conclusion & $5,10,15,20,25,30,35,40$ \\
\hline
\end{tabular}

Before the test was administered to the students, the test material was tried out to the students who were not involved as the sample in this study. The try out was conducted to find out the validity and reliability of the test. Heaton (1975:172) says that from the try out, it could be seen whether the index of 
difficulty of a particular item is easy or difficult. To find out the difficulty level of the item, the following formula is used:

F. $\mathbf{V}=\frac{R}{N}$

Where:

$\mathrm{F} . \mathrm{V}=$ the index of difficulty

$\mathrm{R}=$ the number of the correct answer

$\mathrm{N}$ = the number of the students taking the test (Heaton, 1975:178)

The test items are accepted if the score is between 0.3-0.7. But, if the score is less than 0.3 (too difficult) and over 0.7 (too easy), it means that they are rejected (Heaton (1975:173).Item discrimination shows us the extent to which the items discriminate between the students separating the more able students from the less able one. It is calculated by using the formula below:

$\mathrm{D}=\underline{\text { Correct } U}-$ Correct $L$

$1 / 2 N$

Where:

$\mathrm{D}=$ discrimination index

$\mathrm{U}=$ upper group answering (upper half)

$\mathrm{L}=$ lower group answering (lower half)

$\mathrm{n}=$ the number of candidates in one group, (Heaton, 1975: 180)

After knowing the difficulty level of the try out test items, the researcher measured the researcher the central tendency by using the mean score. To know the average score of the students' ability in comprehending the texts, the writer presented the data by using the formula:

$$
M=\frac{\sum f x}{N}
$$

The explanation:

$\mathrm{M} \quad=$ the mean of the score in each topic

$\sum f x \quad=$ the sum of respondent's score

$\mathrm{N} \quad=$ Number of respondent, Hatch and Farhady (1982:55)

The mean score by itself enables to describe an individual student's score but it does not tell about the highest and the lowest scores and the spread of scores. To know about them, the researcher used Standard Deviation (s.d) 
formula. The Standard Deviation is one of the ways to show the spread of marks. The standard deviation formula is:

$$
S D=\sqrt{\frac{\sum d^{2}}{N-1}}
$$

The explanation:

$\mathrm{SD}=$ standard deviation

$\mathrm{N}=$ the number of items

$\mathrm{d}=$ the deviation of each score from the mean, Heaton (1991:177)

The next step is to compute the reliability of the test. According to Heaton, (1991) reliability is a necessary characteristic of a good test. In order to find the reliability of the test, the following formula is used:

$$
R^{i i}=\frac{N}{N-1}\left[1-\frac{m(N-m)}{N x^{2}}\right]
$$

Where:

$\mathrm{N}=$ the number of the items in the test

$\mathrm{M}=$ the mean score of the try out test

$\mathrm{x}=$ the standard deviation of the try out

$\mathrm{R}^{i i}=$ reliability, (Heaton, 1991: 164)

\section{Data Analysis Technique}

To know the students' scores in answering the test, the following formula is used:

$$
\mathbf{M}=\frac{X}{N} \times 100
$$

(Wayan and Sumartana, 1986)

The explanation:

$$
\begin{aligned}
& \mathrm{M}=\text { individual score } \\
& \mathrm{X}=\text { the number of correct answers } \\
& \mathrm{N}=\text { the number of items }
\end{aligned}
$$

To find out the mean score of the students in comprehending the procedure texts, the following formula is used: 


$$
M=\frac{\Sigma f x}{N}
$$

The explanation:

$\mathrm{M} \quad=$ mean score

$\Sigma f \mathrm{x}=$ the summation of the respondents' scores

$\mathrm{N} \quad=$ the number of respondents, (Hatch and Farhady 1982:55)

Then, to categorize the level of the students' ability in comprehending procedure texst, the following scale is used:

\section{Table 2: The Classification of the Students' Scores}

\begin{tabular}{|c|c|}
\hline The Classification of Scores & Categories of Scores \\
\hline $81-100$ & Excellent \\
\hline $61-80$ & Good \\
\hline $41-60$ & Mediocre \\
\hline $21-40$ & Poor \\
\hline $0-20$ & Very poor \\
\hline
\end{tabular}

Sources: Harris, 1969 in Hanyva, 2002:19

To know the percentage of the classification of the students' ability in comprehending procedure texts, the following formula is used:

$$
\mathbf{P}=\frac{F}{R} \times 100 \%
$$

The explanation:

$\mathrm{P}$ = percentage

$\mathrm{F}$ = frequency

$\mathrm{R}=$ Total number of respondents, (Hatch and Farhady, 1986:55)

\section{RESULTS AND DISCUSSION}

\section{Individual Score}

In order to find out the individual score of each student, the writer divided the number of the correct answers with the total number of items and then multiplied it by one hundred (100).

The students' scores and their level of ability classification are varied. From 40 students, 1 student (2.5\%) gets the score of 75 and 1 student (2.5\%) gets the score of $72.5,1$ student (2.5\%) gets the score of 70,1 student $(2.5 \%)$ gets the score of $67.5,5$ students (12.5\%) get the score of 65 , and 4 students (10\%) get the 
score of 62.5. In other words, 13 students (32.5\%) are in good level. 7 students (17.5\%) get the score of 60,5 students (12.5\%) get the score of $57.5,4$ students (10\%) get the score of 55, 4 students (10\%) get the score of $52.5,3$ students (7.5\%) get the score of 50, and 2 students (5\%) get the score 37.5. In other words, 25 students (62.5\%) are in mediocre level. 2 students (5\%) get the score of 37.5 are in poor level. And no student (o\%) is in excellent and very poor level.

The mean score of the second year students of SMP N 18 Pekanbaru in comprehending procedure texts is 57.81 . Therefore, it can be stated that the students' score is in mediocre level. Table 1 also shows that the highest score obtained by the students is 75 and the lowest score is 37.5 .

The percentage of the students' scores and their level of ability classification in all level vary. From 40 students, no student (o\%) is in excellent level and very poor level, 13 students (32.5\%) are in good level, 25 students (62.5\%) are in mediocre level, and 2 students (5\%) are in poor level.

After finding the students' individual scores in comprehending procedure texts, the writer examined their ability in terms of finding main idea, factual information, meaning of difficult word, identifying reference, and making restatement based on the classification of the questions as stated in the blue print of the instrument. They are important indicators if we want to know the students' ability in comprehending procedure texts.

\section{The Students' Ability in Finding Main Idea}

The students' ability in finding main idea varies. From 40 students, 1 student (2.5\%) gets the score of 100 and 4 students (10\%) get the score of 87.5. In other words, 5 students (12.5\%) are in excellent level. 9 students (22.5\%) get the score of 75 and 15 students (37.5\%) get the score of 62.5. In other words, 24 students (60\%) are in good level. 3 students (7.5\%) get the score of 50 are in mediocre level. 6 students (15\%) get the score of 37.5 and 1 student (2.5\%) gets the score of 25. In other words, 7 students (17.5\%) are in poor level. 1 student (2.5\%) gets the score of 12.5 (2.5\%) is in verypoor level.

The mean score of the students is 61.87 . Therefore, it can be stated that the students' ability in finding main ideas is in good level. Table 3 also shows that the highest score obtained by the students is 100 and the lowest score is 12.5 . The percentage of the students' ability in finding main idea varies. From 40 students, 5 students (12.5\%) are in excellent level, 24 students (60\%) are in good level, 3 students (7.5\%) are in mediocre level, 7 students (17.5\%) are in poor level and 1 student $(2.5 \%)$ is in very poor level. It means that the students' ability in finding main idea is in good level.

\section{The Students' Ability in Finding Factual Information}

The students' ability in finding factual information varies. From 40 students, 4 students (10\%) get the score of 87.5. In other words, 4 students are in 
excellent level. 12 students (30\%) get the score of 75 and 12 students (30\%) get the score of 62.5. In other words, 24 students (60\%) are in good level. 8 students (20\%) get the score of 50 . In other words, 8 students are in mediocre level. 2 students (5\%) get the score of 37.5 and 1 student (2.5\%) gets the score of 25 . In other words, 3 students (7.5\%) are in poor level. 1 student $(2.5 \%)$ gets the score of 12.5. In other words, 1 student is in very poor level.

The Percentage of the students' ability in finding factual information varies. From 40 students, 4 students (10\%) are in excellent level, 24 students (60\%) are in good level, 8 students (20\%) are in mediocre level, 3 students (7.5\%) are in poor level and 1 student (2.5\%) is in very poor level. It means that the students' ability in finding factual information is in good level.

\section{The Students' Ability in Finding Meaning of Difficult Word}

The students' ability in finding meaning of difficult word varies. From 40 students, 2 students (5\%) get the score of 100 and 4 students (10\%) get the score of 87.5. In other words, 6 students (15\%) are in excellent level. 11 students (27.5\%) get the score of 75 and 10 students (25\%) get the score of 62.5. In other words, 21 students (60\%) are in good level. 10 students (25\%) get the score of 50. In other words, 10 students are in mediocre level. 2 students (5\%) get the score of 37.5. In other words, 2 students are in poor level. 1 student (2.5\%) gets the score of 12.5. In other words, 1 student is in very poor level.

The percentage of the students' ability in finding meaning of difficult word varies. From 40 students, 6 students (15\%) are in excellent level, 21 students (52.5\%) are in good level, 10 students (25\%) are in mediocre level, 2 students (5\%) are in poor level and 1 student (2.5\%) is in very poor level. It means that the students' ability in finding meaning of difficult word is in good level.

\section{The Students' Ability in Identifying Reference}

The students' ability in identifying reference varies. From 40 students, 3 students (7.5\%) get the score of 75 and 8 students (20\%) get the score of 62.5. In other words, 11 students (27.5\%) are in good level. 13 students (32.5\%) get the score of 50 . In other words, 13 students are in mediocre level. 9 students (22.5\%) get the score of 37.5 and 5 students (12.5\%) get score of 25. In other words, 14 students (35\%) are in poor level. 2 students (5\%) get the score of 12.5 . In other words, 2 students are in very poor level. No student (o\%) is in excellent level.The mean score of the students is 46.56 . Therefore, it can be stated that the students' ability in identifying reference is in mediocre level.

The percentage of the students' ability in identifying reference varies. From 40 students, no student (o\%) is in excellent level, 11 students (27.5\%) are in good level, 13 students (32.5\%) are in mediocre level, 14 students (35\%) are in poor level and 2 students (5\%) are in very poor level.

\section{The Students' Ability in Making Restatement}


The students' ability in making restatement varies. From 40 students, 2 students (5\%) get the score of 87.5. In other words, 2 students are in excellent level. 10 students (25\%) get the score of 62.5. In other words, 10 students are in good level. 12 students (30\%) get the score of 50. In other words, 12 students are in mediocre level. 13 students (32.5\%) get the score of 37.5 and 3 students $(7.5 \%)$ get the score of 25. In other words, 16 students (40\%) are in poor level. No student (o\%) is in very poor level.The mean score of the students is 49.06. Therefore, it can be states that the students' ability in making restatement is in mediocre level. The percentage of students' ability in making restatement varies. From 40 students, 2 students (5\%) are in excellent level, 10 students (25\%) are in good level, 12 students (30\%) are in mediocre level, and 16 students (40\%) are in poor level and no student (o\%) in very poor level.

\section{The Students' Mean Scores in Comprehending Procedure Texts}

Classification of questions: finding main ideas, finding factual information, identifying references, and making restatement is in mediocre level. The most difficult aspect in comprehending procedure texts is identifying reference, with the score of 46.56 . Then the easiest aspect is in finding meaning of difficult word, with the score of 64.69.

\section{The Interpretation of Research Finding}

As it has been discussed in the previous chapter, the writer tried to find out the answer to the question related to the ability of the second year students of SMPN 18 Pekanbaru in Comprehending Procedure Texts. After analyzing the data, the writer found out that the students' ability in comprehending procedure texts is at mediocre level. It can be seen from the mean score of the students which is 57.81 .

From the five components of reading comprehension, the writer found that the highest score obtained by students in comprehending procedure texts is in finding meaning of difficult words with the mean score of 64.69. It is in good level. The mean scores of finding main ideas and finding factual information are also in good level. The students' mean score in terms of making restatement is at mediocre level. The lowest mean score is in terms of identifying references with the mean score of 46.56 , it is in mediocre level.

\section{CONCLUSIONS AND SUGGESTIONS}

\section{Conclusions}

The objective of this study is to find out the ability of the second year students of SMP N 18 Pekanbaru in comprehending procedure texts. Based on the result of the data analysis in chapter IV, the writer makes some conclusions. Among 40 students, no student (o\%) is in excellent level and very poor level, 13 
students (32.5\%) are in good level, 25 students (62.5\%) are in mediocre level, 2 students $(5 \%)$ are in poor level. The mean score of the whole students in comprehending procedure texts is 57.81 . In conclusion, the ability of the second year students of SMP N 18 Pekanbaru in comprehending procedure texts is at mediocre level.

Since the research dealt with comprehending procedure texts, the writer drew conclusions for each classification of comprehending procedure texts. In terms of finding main idea, from 40 students, 5 students (12.5\%) are in excellent level, 24 students (60\%) are in good level, 3 students (7.5\%) are in mediocre level, 7 students (17.5\%) are in poor level and 1 student (2.5\%) is in very poor level. In terms of finding factual information, 4 students (10\%) are in excellent level, 24 students (6o.\%) are in good level, 8 students (20\%) are in mediocre level, 3 students (7.5\%) are in poor level and 1 student $(2,5 \%)$ is in very poor level. In terms of finding meaning of difficult word, 6 students (15\%) are in excellent level, 21 students (52,5\%) are in good level, 10 students (25\%) are in mediocre level, 2 students (5\%) are in poor level and 1 students (2.5\%) is in verypoor level. In terms of identifying reference, no student (o\%) is in excellent level, 11 students (27.5\%) are in good level, 13 students (32.5\%) are in mediocre level, 14 students (35\%) are in poor level and 2 students (5\%) are in very poor level. In terms of making restatement, from 2 students (5\%) are inexcellentlevel, 10 students (25\%) are in good level, 12 students (30\%) are in mediocre level, 16 students (40\%) are in poor level and no student (o\%) is in very poor level.

\section{Suggestions}

After doing the research on the ability of the second year students of SMPN 18 Pekanbaru in comprehending procedure texts, the writer would like to give some suggestions. First, the English teacher should give more explanation and more exercises in comprehending procedure texts, especially in finding main ideas, the meaning of difficult words, references, factual information, and restatements. The teacher also needs to apply some reading strategies which are suitable for the students. There are some strategies that can be applied by teacher such as: skimming, scanning and guessing unknown words.

Second, the students should motivate themselves to read more reading materials, especially procedure texts. More practice, more we can get. In other words, the students also need to enjoy reading because there will be many advantages that they can get.

Finally, the writer hopes that this study gives valuable contribution to the students, the teachers and the readers in terms of reading comprehension especially reading procedure texts which include five components, finding main idea, finding factual information, identifying meaning of difficult words, identifying references, and making restatement. 


\section{BIBLIOGRAPHY}

Azhar, Fadly.2004. PedomanPenyusunandanpenyelenggaraanUjianSkripsi di Prodi BahasaInggrisJurusanPendidikanBahasadanSeni FKIPUNRI.Pekanbaru: Faculty of Teachers' Training and Education. (Unpublished)

Burnes, Don. 1985. Insights and Strategy for Teaching Reading. Australia: National Library of Australia Cataloguing - in - Publication Data.

Buss, Kathleen et al. 2004. Reading and Writing Nonfiction Genres. International Reading Association, Inc.

Carrel et al 1998. Interactive Approaches to Second Language Reading.Cambridge University Press. United States of America

DepartementPendidikanNasional. 2003. Standard Kompetensi Mata PelajaranBahasaInggris. Jakarta: PusatKurikulum, BalitbangDepdiknas.

Derewianka, Baverly. 2001. Using Functional Exploring how to work. Australia: National Library.

Djuharie, OtongSetiawan. 2007. Genre. Bandung: YramaWidya

Gay, L.R. 2000.Educational Research Competencies for Analysis and Application. New Jersey: Prentice-Hall, Inc.

Harmer, Jeremy. 2002. The Practice of English Language Teaching. Malaysia: Longman.

Hartono, Rudi. 2005. Genre of texts. Faculty of Language and Art.Universitas Semarang.

Hatch, E and Farhady, H. 1982.Research Design and Statistics for Applied Linguistic. Los Angeles: University of California.

Heaton, J.B. 1975. A Practical Guide for Teacher of English as a Second or Foreign Language. London: Longman.

Heinemann, Rifby. 2004. Writing Resource Book. Australia: Advance Press.

Hong, Zhi. 2007. The Effect of Learning Strategies on Reading Comprehension. Retrieved February 2, 2010 from, http://www.lingust.org.cn/doc/su200704/su20070404.pdf

Hornby, A.S. 2000.Oxford Advance Learners' Dictionary.Oxford: Oxford University Press

Nuttal, Christine. 1982. Teaching English in Foreign Language. Great Britain: The Bath Press

Sofyan, Fahmi. 2008. KiatSukses Lulus UjianBahasaInggris. Jakarta: PustakaTarbiyahBaru

Stanley, M and King 2004.Building Skill for TOEFL, BinaAksara, Jakarta

Sudjana. 1998. MetodeStatika. Bandung: PenerbitTarsito

Wayan and Sumartana. 1986. Evaluasi Pendidikan. Surabaya: Penerbit Usaha Nasional

http://www.wikipedia. "Reading Comprehension" 2 February 2010

http://www.wikipedia. ”Procedure Text" 2 February 2010 